\title{
Strategic green infrastructure planning in Germany and the UK: a transnational evaluation of the evolution of urban greening policy and practice
}

\author{
Ian Mell, Simone Allin, Mario Reimer \& Jost Wilker
}

To cite this article: Ian Mell, Simone Allin, Mario Reimer \& Jost Wilker (2017): Strategic green infrastructure planning in Germany and the UK: a transnational evaluation of the evolution of urban greening policy and practice, International Planning Studies, DOI: 10.1080/13563475.2017.1291334

To link to this article: http://dx.doi.org/10.1080/13563475.2017.1291334

Published online: 15 Feb 2017.

Submit your article to this journal $\sqsubset$

Џll Article views: 41

Q View related articles $\sqsubset$

View Crossmark data ¿ 


\title{
Strategic green infrastructure planning in Germany and the UK: a transnational evaluation of the evolution of urban greening policy and practice
}

\author{
Ian Mell ${ }^{\mathrm{a}}$, Simone Allin ${ }^{\mathrm{b}}$, Mario Reimer ${ }^{\mathrm{c}}$ and Jost Wilker ${ }^{\mathrm{d}}$

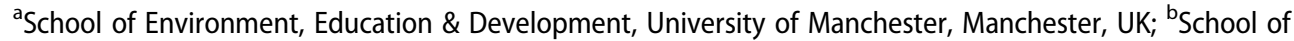 \\ Architecture, Design and the Built Environment, Nottingham Trent University, Nottingham, UK; ' ILS - Research \\ Institute for Regional and Urban Development, Dortmund, Germany; ${ }^{d}$ Ministry for Climate Protection, Environment, \\ Agriculture, Conservation and Consumer Protection of the State of North Rhine-Westphalia (MKULNV), Düsseldorf, \\ Germany
}

\begin{abstract}
The evolution of Green Infrastructure (GI) planning has varied dramatically between nations. Although a grounded set of principles are recognized globally, there is increasing variance in how these are implemented at a national and sub-national level. To investigate this the following paper presents an evaluation of how green infrastructure has been planned for in England and Germany illustrating how national policy structures facilitate variance in application. Adopting an evaluative framework linked to the identification of $\mathrm{Gl}$, its development and monitoring/ feedback the paper questions the impacts on delivery of intersecting factors including terminology, spatial distribution and functionality on effective $\mathrm{Gl}$ investment. This process reviews how changing policy structures have influenced the framing of green infrastructure policy, and subsequent impact this has on the delivery of green infrastructure projects.
\end{abstract}

\section{KEYWORDS}

Green infrastructure; planning policy; policy networks; governance; Europe

\section{Introduction}

Green infrastructure planning is now broadly considered by planners to have evolved to meet a diverse range of landscape and urban planning issues. Furthermore, in each of the main areas which have supported its development, that is, the UK, Europe and North America, we have seen a growing confluence of principles presented as 'green infrastructure'. Nevertheless, within these debates there are ongoing discussions borne out in both the academic and practitioner literature, which reflect the promotion of distinctly localized interpretations of the concept, rather than a global norm of how green infrastructure is used to frame investment (Mell 2014, 2016). As a consequence it is difficult for researchers (cf. Lennon 2014) to (a) establish a trans-locationally accepted definition of the concept or (b) identify consistent cross-boundary values, implementation practices or policy structures for green infrastructure planning (Austin 2014; Hansen and Pauleit 2014).

Identifying whether comparable approaches to investment in green infrastructure exist has, thus, become a prominent narrative within landscape planning debates (Benedict and McMahon 2006). Establishing what green infrastructure is, how it is developed and why it is important to integrate landscape issues within urban planning has provided advocates with a toolkit of options to approach development. To date though there have been limited attempts to rationalize 'local' green 
infrastructure implementation within such a 'global narrative' (cf. Andersson et al. 2014). Alternatively, we witness a growing number of sub-national or localized assessments rather than an integrated international approach. The outcome of which suggests that although a confluence of principles, that is, connectivity, multi-functionality, access and sustainable landscape/water management are evident between territorial interpretations, there remain explicit local variations in the structures of national and sub-national planning approaches to green infrastructure (European Commission 2013; Werquin et al. 2005).

To investigate these differences this paper presents a comparative analysis of green infrastructure planning in two of key green space planning locations in Europe, England and Germany, to assess whether, and if so, how the concept of green infrastructure is being integrated into landscape policy and planning practice. England and Germany are used as exemplar case studies as they both have planning systems with established landscape policy that proposes, at least in part, to discuss green infrastructure (Mell 2014; Wilker and Rusche 2014). ${ }^{1}$ Both locations also have a history of innovation in terms of landscape planning - specifically in terms of landscape rehabilitation in postindustrial landscapes (Beatley 2000). Such a comparative assessment helps us to engage in a more evidence-based debate regarding the transferability of green infrastructure principles into praxis, and through an examination of good-practice we can identify if, and where, policy and implementation silos exist in England and Germany. The review of current experience reported in this paper therefore proposes a parallel commentary to the normative policy narratives presented within the mainstream planning literature in Germany and England illustrating where translatable praxis exists (Albert and Von Haaren 2015; Allin 2011; Hansen et al. 2015). The paper's authors have also, and continue to be involved in green infrastructure policy-making, research and investment in both locations providing them with valuable in-situ insights into the structural mechanisms that support, and the barriers which limit, investment in green infrastructure. This latter experience is used to contextualize practitioner knowledge of implementation alongside evaluation of existing policy reported in the literature.

Using 'green infrastructure' as a thematic framing this paper examines the factors which influence the production of green infrastructure policy, and its subsequent delivery. However, even when established evaluative schema are used to support an emerging confluence of policy/practice, such as those proposed by Alexander and Faludi (1989) or Carneiro (2013), they often lack transferability. Furthermore, as Peel and Lloyd (2005) argue where concepts become grounded in global debates there remains an inherent variance in geo-political contextualization, which can lead to divergence in implementation. By exploring the nuances of stakeholder-policy-practice relationships with green infrastructure against established evaluative frameworks, we examine how the spatial and territorial structures of planning in England and Germany have impacted upon the concept's development. This analysis identifies the variability of meaning, and the focus of policy/practice to illustrate the influence that different planning cultures have on green infrastructure management and implementation. The paper concludes with a discussion of:

(a) Whether or not a comparable process of green infrastructure investment can be identified between England and Germany;

(b) How evaluative frameworks assist our understanding of this process.

Whilst the following sections present arguments addressing (a) and (b), the paper acts as a catalyst to generate dialogue between policy-makers, practitioners and academics to consider whether transferable praxis can be identified, applied and scaled-up or translated to other locations: a hypothetical point (c). Moreover, by presenting a framework that promotes an initial comparative assessment of transferability the paper emphasizes our understanding of the context that green infrastructure is being developed within, and whether locally specific practices can be transposed between locations. To rationalize the analysis, the following section briefly contextualizes the broader global narratives of green infrastructure, its meanings and uses to date. 


\section{Contextualizing green infrastructure: terminology, policy and application}

Green infrastructure is regarding by some commentators as a hybridized concept (Mell 2016). Its antecedents are drawn from landscape ecology (Jongman and Pungetti 2004), green belt thinking (Amati and Taylor 2010), greenways planning (Fábos 2004) and the Garden Cities movement (Town \& Country Planning Association 2012), as well as the literature on water-centric management/development (Ahern 2007); all of which have provided advocates with a wide-ranging set of principles to frame its use (Roe and Mell 2013). There are currently as many interpretations of green infrastructure as there are people engaging with the concept, and like most definitions these reflect the focus of specific researchers or organizations. Conservationist authors emphasize the value of planning for biodiversity (Benedict and McMahon 2006); planners review the concept in terms of delivering societal benefits (Kambites and Owen 2006); engineers assess the integrative nature of systems and the growing understanding of urban storm water and catchment-scale management (Austin 2014; Marcucci and Jordan 2013); whilst, greenway specialists focus on the delivery of socio-ecological benefits across urban/urban-fringe landscapes (Fábos 2004). Therefore, although diversity is inherent in all the proposed definitions of green infrastructure it can, and has been, argued that a series of aspatial and universal themes underpin each interpretation. Each definition, for example, Austin (2014), Mell (2010) or Benedict and McMahon (2006), thus provides insights into the complexity of aligning green infrastructure planning at alternative and occasionally competing scales, promoting connectivity and multi-functionality, and developing more efficient ecological, economic and social places.

These discussions drove the evolution of the concept from the late 1990s onwards, and resulted in the creation of a series of definitions; most noticeably those of Benedict and McMahon (2006), Natural England (2009), but more recently the European Commission (2013). Of the proposed definitions Benedict and McMahon's has received most credence:

Green infrastructure is our nation's natural life support system - an interconnected network of waterways, wetlands, woodlands, wildlife habitats, and other natural areas; greenways, parks and other conservation lands; working farms, ranches and forests; and wilderness and other open spaces that support native species, maintain natural ecological processes, sustain air and water resources and contribute to the health and quality of life for America's communities and people. $(2001,6)$

Within their definition Benedict and McMahon note the interactivity of social, ecological and economic factors within a spatially diverse approach to landscape management. Thus, they promote cross-boundary integration and co-operation in landscape resource management; a notion which McHarg (1969) noted is often overlooked in planning.

From a reading of the green infrastructure literature we can identify a clustering of principles used to support its use centred on a number of locations. North American discussions predominately focus on water management/quality issues (Ahern 2007) or biodiversity (Weber, Sloan, and Wolf 2006), and the roles played by national and regional agencies, as well as environmental advocates for example the Conservation Fund or the Army Corps in delivery (Mell 2016), whereas in England there has been a greater discussion of the socio-ecological factors framing landscape planning (Blackman and Thackray 2007). In Europe we can identify within the Valuing Attractive Landscapes in the Urban Economy (VALUE) project (funded by the European Union) a form of green infrastructure planning that bridges technocratic planning with the holistic thinking noted in Dutch, Belgian and German systems (South Yorkshire Forest Partnership \& Sheffield City Council 2012). This helps to illustrate that although we may not need to a fully rationalize what green infrastructure is to facilitate development we can identify a set of principles that have become established to assist this.

Wright (2011) and Mell $(2014,2013)$ extended this discussion debating whether the diversity of thinking within green infrastructure had promoted consensus regarding its use. Within their debate the confluence of understanding of what green infrastructure is was suggested as a key mechanism contextualizing its meaning to stakeholders, in plan-making activities, and in delivery (Lennon 2014; Llausàs and Roe 2012). However, the geo-spatial differences in application, the fluidity of political 
and advocate support, and the flexibility of approaches to landscape planning was identified as being less significant by Wright but an important factor in framing these discussions, and subsequent evaluations of green infrastructure by other commentators, for instance Austin (2014).

The following sections explore this issue identifying if an integrated, strategic and transferable structure for green infrastructure is visible between England and Germany or alternatively whether localized territorial approaches are more influential. Wright (2011) argued that attempts to establish a trans-locational consensus could prove counter-intuitive, especially where the main driver of application is based on a more localized understanding of policy, advocacy and delivery rather than a global discourse. However, despite Wright's critique the development of green infrastructure planning has been rapid, and at times researchers have failed to take into account the temporal complexities of uptake to engineer acceptance for the concept. This reflects Rydin's discussion of the extended timeframe needed to embed new concepts within policy-making (Rydin 2013). Using Rydin's evaluation as a starting point, we argue that green infrastructure planning is evolving; especially when it is positioned as a future-oriented process where the desired outcome of development is sustainability. As a consequence new interpretations of green infrastructure are consistently being developed with examples now being reported by engineers, health practitioners, as well as urban planners (Hale and Sadler 2012; Ward Thompson, Aspinall, and Bell 2010).

\section{An evaluative framework for green infrastructure planning}

Framing the fluidity of green infrastructure planning requires an understanding of the structural policy and practice mechanisms that support its effectiveness as a form of landscape management. How policy is conceived can be seen as a dialogue between normative processes of investment and more coercive forms of policy-making that attempt to establish both clarity of expression and parity between stakeholders (Van Den Brink, Van Der Valk, and Van Dijk 2006). Establishing a balance between 'policy convergence and policy divergence over spatial territories are indicative of the increasingly critical reflective approach to public policy making' (Peel and Lloyd 2005, 266), is therefore crucial.

Within global discussions of green infrastructure there is little evidence that such a trans-locational consensus exists. Although we can consider, as noted previously, that a global set of principles underpins its use, when we focus the evaluative lens on comparisons of national and sub-national practice we see greater variance in approach, application and structural/institutional support (Mell 2014). Global discussions of green infrastructure could therefore be perceived as providing a conceptual framework through which more localized interpretations can be made. The structural variability of national and sub-national planning, as a consequence, has a greater influence on the application of these ideas in practice. Reviewing the mechanisms used to evaluate the effectiveness of green infrastructure planning in individual countries therefore provides us with an indication of how the concept is being translated at a number of national and sub-national scales, and secondly, how it is integrated into existing planning frameworks.

The variability of policy, implementation and evaluation of green infrastructure, and its globalized principles, has been witnessed within the academy, by practitioners around the world, and by the paper's authors (Mell 2013; Wright 2011). Over a 10-year period there has been an ongoing debate reflecting how to establish best practice to communicate the values of green infrastructure (Austin 2014; James et al. 2009; Mell 2016). To date there has been no accepted narrative that appreciates the nuances of these discussions. Thus, we propose that there is a requirement for academic discussions to be more closely aligned with policy-makers, practitioners and delivery agents to evaluate the progression (and uptake) of green infrastructure thinking.

Drawing on previous research findings published in the academic literature and in collaboration with partners in Europe, North America and Asia this paper uses the 'real-world' experiences of its authors (at a local, regional and national scale) in conjunction with the academic discussions proposed in journals and policy/practice guidance to contextualize the promotion of a more effective 
and transferable understanding of green infrastructure (cf. Allen 2012; Mell 2014; Roe and Mell 2013; Siemens AG 2011; Vandermeulen et al. 2011; Wilker and Rusche 2014). Firstly, the paper uses a range of policy, practice and academic sources focussed on the development of green infrastructure globally to contextualize the paper before examining how these materials are discussed in Germany and England to provide locally specific analysis. The selection and use of materials is based on a review of the established green infrastructure literature, and the knowledge of the paper's authors drawing on experience in the development and application of the concept.

It is our contention that in spite of the fluidity of green infrastructure planning by different territorial administrations/stakeholders that a common process of policy-practice can be identified, as proposed in our hypothetical objective (c). We also contend that the processes developed by Alexander and Faludi (1989) and Carneiro (2013) can be adapted to provide an evaluative framework to examine the progression of green infrastructure thinking, policy-making and latterly implementation. For example the complementarity of elements of the British and Irish planning systems suggests that policy is comparable despite procedural differences (Lennon 2014). Whilst, in The Netherlands and Belgium similar approaches to water resource and landscape management can be identified (South Yorkshire Forest Partnership \& Sheffield City Council 2012). Furthermore, the development of regional-scale green infrastructure in Germany has been viewed as an investment framework that can potentially be applied in other European countries (Albert and Von Haaren 2015; Liebenath, Blum, and Sturzriemer 2010). Examples therefore exist which illustrate where principles have been implemented that transcend administrative boundaries. However, we acknowledge that in federalized states such as Germany (or the USA) that this process is not always effective (Benedict and McMahon 2006; Rouse and Bunster-Ossa 2013; Wilker, Rusche, and Rymsa-Fitschen 2016).

Further analysis highlights the added complexity that implementation at a number of scales in different sovereign nations embeds within planning decision-making. Moreover, environmental resources (and/or their management) rarely function at a single scale. Rather, they are spatially diverse and function across territorial, administrative and legal boundaries. As a consequence although the research literature (cf. Lafortezza et al. 2013; Mazza et al. 2011) supports the application of cross-administration green infrastructure planning, in practice it remains difficult to apply its principles outside of territorially distinctive policy. Thus, if we acknowledge green infrastructure as a multi-scale form of investment, as illustrated in the literature (cf. Benedict and McMahon 2006), we can argue that it is logical to plan at a meta-scale rather than dealing with issues in territorial isolation (Van Den Brink, Van Der Valk, and Van Dijk 2006). Extending this discussion, we can hypothesize how a collective understanding of green infrastructure could be integrated into the planning structures of different European countries. Using the evaluative frameworks of Alexander and Faludi (1989) and Carneiro (2013) as a starting point, we discuss whether an adaptive process exists that supports the uptake of green infrastructure in England and Germany, and whether it offers comparable or translatable insights into how green infrastructure is developed. The following proposes a three-stage framework to examine whether this is possible.

The frameworks presented by Alexander and Faludi (1989) and Carneiro (2013) proposed threestage approaches focussing on: evolution and rationality, performance in practice, and function and conformance, which loosely equate to our conceptions of understanding an issue (scoping and development), planning for it (implementation), and then evaluating our approaches to praxis (analysis/ evaluation), as shown in Figure 1. This three-stage process will form the basis for the evaluation presented. For example, Peel and Lloyd (2005) examined these issues as part of a wider approach to the development of cohesive and territorially appropriate policy. They argued that by establishing clarity between evidence-based research and stakeholder knowledge, that it is easier for decision-makers to generate appropriate policy. This, they argued, was focussed on the setting of deliverable outcomes and followed a normative approach to planning. If we take Peel and Lloyd's position and apply their characterization of effective policy to the evaluative frameworks of Alexander and Faludi (1989) and 


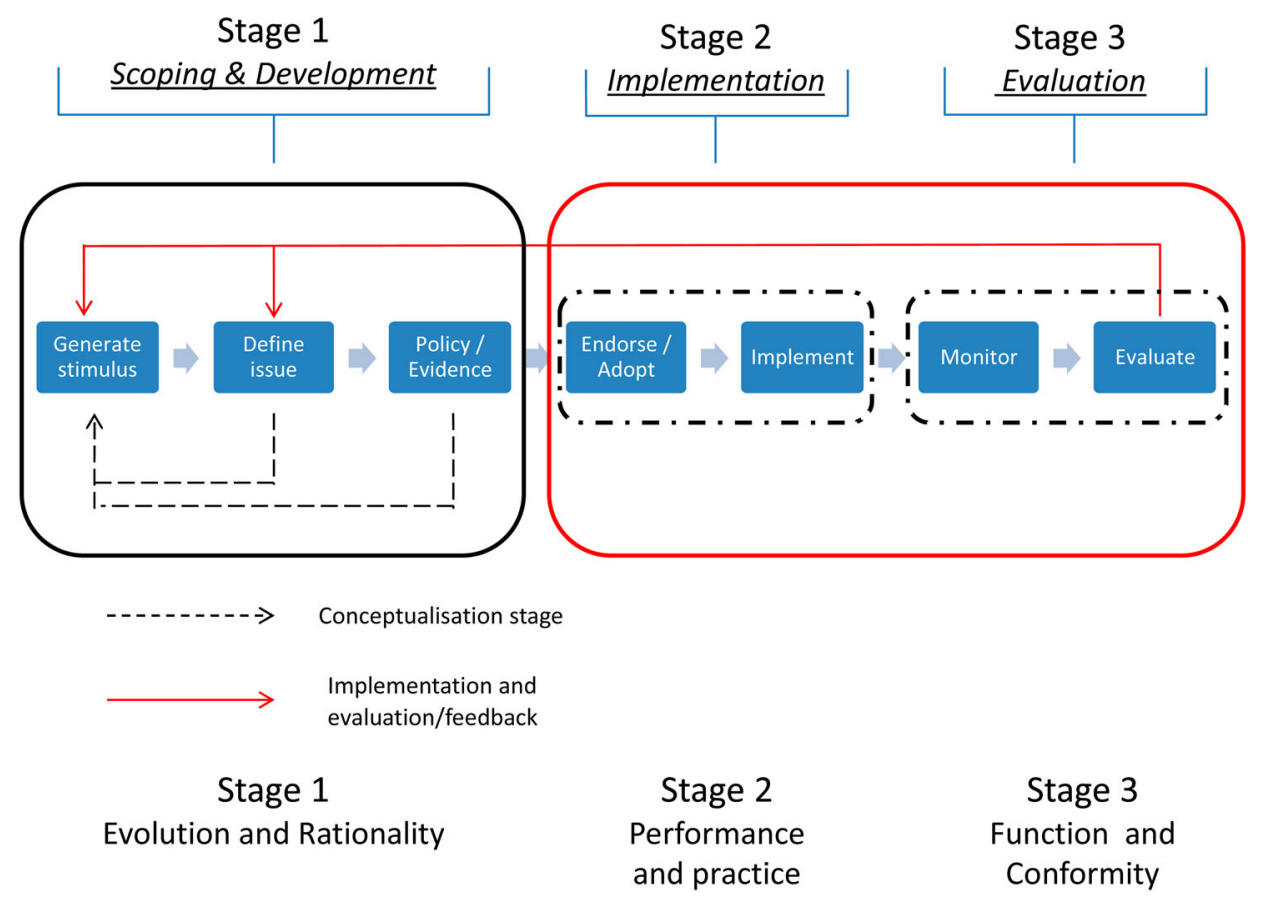

Figure 1. Development, implementation and evaluation feedback process for Green infrastructure (adapted from Alexander and Faludi 1989; Carneiro 2013).

Carneiro (2013) we propose the conceptual framework presented in this paper could support the current/future development of green infrastructure.

The framework, as shown in Figure 1, is constructed as a three-stage approach with each aiming to stimulate an increased level of awareness and technical/implementable knowledge of green infrastructure. We are also aware of the potential overlap between stages, which is not viewed as a hindrance. In order to avoid the continuation of existing institutional and/or territorial silo-thinking the framework proposes a series of transitional steps to link the inclusion of research and policy at each stage with the next. This provides both an expanding evidence base and a feedback mechanism to ensure that clarity of focus and expression are developed at each point in the evaluation process. The three proposed stages are:

\section{Stage 1. Evolution and rationality (Scoping and development)}

Stage 1 implies internal coherence within the planning system that aligns procedural issues and planning contexts to promote continuity, and the facilitation of effective decision-making. The stage establishes responsibilities (national, regional and local level) for planners, developers/stakeholders and citizens which conform to statutory rules and guidance. Secondly, it argues for greater consensus within discussions of green infrastructure identifying its components, objectives, territorial scope and proposed implementation mechanisms. Finally, there is a level of coherence between green infrastructure planning and other policy or management instruments at a national and sub-national scale.

\section{Stage 2. Performance in practice (implementation)}

The second stage identifies consistency between the different scales/structures of a given planning system and the utilization of the concept's main principles. This includes reviewing the value of 
green infrastructure at a (i) management and operational-technical level and (ii) its potentiality as an effective decision-making tool. It also illustrates the benefits that green infrastructure can deliver, the financial implications of investment and the associated temporal and spatial outcomes of this process.

\section{Stage 3. Function and conformity (evaluation)}

The final stage aims to evaluate the effectiveness of scoping, decision-making and implementation activities. This centres on the results of the planning process examining whether outcomes conform to the original investment objectives and overarching goals of 'sustainable landscape management'. This process includes feedback loops to stages 1 and 2, enabling planners and decision-makers to address barriers to development and the potential longer term impacts of delivery with key stakeholders.

To assess the value of the evaluative framework the following approach is taken. As stated in the first section of the paper each of its authors have extensive experience in academic, practitioner and local/regional government development of green infrastructure policy and practice. The understanding of the 'real world' evolution of policy supporting a new concept, that is, green infrastructure, illustrates within the paper the dynamism of socio-economic and political factors influencing planning in both England and Germany (Kambites and Owen 2006; Wilker, Rusche, and Rymsa-Fitschen 2016). However, a reliance on such interpretations would lack validity, hence, the paper aligns experience with an analysis of existing policy/practice discussions presented in published documents, which have been explored to support the observations made. The policy analysed is drawn from the highest profile examples of green infrastructure guidance in Germany and England over a 10-year period. This is systematic in that it represents the most commonly discussed forms of green infrastructure policy, however, it is acknowledged though that other sub-national and advocate-led documents are available but are not discussed as they do not hold the same level of legal or administrative authority in Germany or England. The proposed framework is thus used as a conceptual framing of the key stages used to develop green infrastructure policy, although it extends this to question the extent and rationale for evaluating implementation - an area often overlooked in the research literature (Mell 2010, 2016; Table 1).

The following two sections apply the proposed framework in Germany and England to examine the development, focus and utilization of green infrastructure to illustrate whether continuity can be identified, and asks if there is comparability of approach reflecting the evaluation framework proposed.

\section{Green infrastructure planning in Germany}

One of the most dominant trends in spatial and sectoral planning in Germany in recent years is the increasing popularity of informal approaches such as strategic masterplans, which are now widely used in order to complement formalized planning frameworks (Allin 2011; BBSR 2014; Blotevogel et al. 2014; Henckel, von Kuczkowski, and Lau 2010). Primarily, this appears to be a consequence of the lack of flexibility and responsiveness of formal planning structures, especially addressing shortterm changes and issues. Such challenges became increasingly prevalent as a spatial consequence of socio-economic developments following German re-unification in 1990. This left many local authorities in both East and West Germany confronted with fundamental changes in their approaches to urban development facilitating a need to update and reconsider local and regional planning policies and practices. The following provides a review of the multi-layered system of formal landscape planning representing a sectoral perspective on green infrastructure planning and management, as well as informal approaches in Germany summarizing the evolution and uptake of green infrastructure thinking and planning through the evaluative framework proposed in this paper. 
Table 1. Global, German and UK characteristics, policy and best practice of Green infrastructure.

\begin{tabular}{|c|c|c|c|}
\hline & Global & Germany & UK \\
\hline $\begin{array}{l}\text { Key principles of } \\
\text { Green } \\
\text { Infrastructure }\end{array}$ & $\begin{array}{l}\text { Water-sensitive design, } \\
\text { catchment management, } \\
\text { ecological sustainability, } \\
\text { connectivity, landscape-scale } \\
\text { management, sustainable } \\
\text { urban design, aesthetic } \\
\text { improvements, access to nature, } \\
\text { ecosystems services and } \\
\text { biodiversity management, } \\
\text { economic development }\end{array}$ & $\begin{array}{l}\text { Multi-functionality, landscape } \\
\text { management, flood prevention, } \\
\text { development of wetlands and } \\
\text { biotope networks, and (urban) } \\
\text { green and open spaces in } \\
\text { general. }\end{array}$ & $\begin{array}{l}\text { Multi-functionality, landscape } \\
\text { connectivity, accessibility, } \\
\text { biodiversity, water management, } \\
\text { sustainable urban development }\end{array}$ \\
\hline $\begin{array}{l}\text { Responsible } \\
\text { authority for } \\
\text { Green } \\
\text { Infrastructure }\end{array}$ & $\begin{array}{l}\text { National governments, city-level } \\
\text { administrations, international } \\
\text { environmental organizations, } \\
\text { utilities companies, businesses } \\
\text { and developers, federal } \\
\text { agencies }\end{array}$ & $\begin{array}{l}\text { State, regional and local planning } \\
\text { authorities/associations; Public } \\
\text { Private Partnerships }\end{array}$ & $\begin{array}{l}\text { Community Forests, Local Planning } \\
\text { Authorities (LPA), Environmental } \\
\text { Organizations (i.e. Forestry } \\
\text { Commission, Wildlife Trust), } \\
\text { Friends/Community groups }\end{array}$ \\
\hline $\begin{array}{l}\text { Green } \\
\text { Infrastructure } \\
\text { policy (National) }\end{array}$ & & $\begin{array}{l}\text { 'National Strategy for Sustainable } \\
\text { Development', 'National } \\
\text { Strategy on Biological } \\
\text { Diversity', 'Concept Green } \\
\text { Infrastructure' (forthcoming), } \\
\text { 'Green Book Green in the City - } \\
\text { Liveable Future' (White Book } \\
\text { will follow) }\end{array}$ & $\begin{array}{l}\text { National Planning Policy } \\
\text { Framework (NPPF), PPS1 } \\
\text { (revoked), PPS7 (revoked), } \\
\text { PPG17 (revoked) }\end{array}$ \\
\hline $\begin{array}{l}\text { Green } \\
\text { Infrastructure } \\
\text { policy (Regional) }\end{array}$ & $\begin{array}{l}\text { Chicago Wilderness (USA), } \\
\text { Metropolitan Milano (Italy), } \\
\text { Golden Horseshoe Green Belt } \\
\text { (Canada) }\end{array}$ & $\begin{array}{l}\text { Emscher Landschaftspark, Master } \\
\text { Plan Green (Cologne/Bonn), }\end{array}$ & $\begin{array}{l}\text { The Local Plan (GLA), } \\
\text { Cambridgeshire Green } \\
\text { Infrastructure Strategy, 2nd } \\
\text { Edition }\end{array}$ \\
\hline $\begin{array}{l}\text { Green } \\
\text { Infrastructure } \\
\text { policy (Local) }\end{array}$ & $\begin{array}{l}\text { MillionTreesNYC (USA), New Delhi } \\
\text { Biodiversity parks (India), }\end{array}$ & $\begin{array}{l}\text { Stadtlandschaft Berlin - natürlich. } \\
\text { Urban. Produktiv., Freiburg } \\
\text { GreenCity, European Green } \\
\text { Capital Essen (2017); More } \\
\text { Nature in the City (Hannover) }\end{array}$ & $\begin{array}{l}\text { Liverpool Green Infrastructure } \\
\text { Strategy (Mersey Forest) }\end{array}$ \\
\hline $\begin{array}{l}\text { Best practice } \\
\text { examples }\end{array}$ & $\begin{array}{l}\text { Paris urban parks (France), } \\
\text { Chesapeake Bay conversation } \\
\text { (USA), green space/parks } \\
\text { development Shanghai/Suzhou } \\
\text { (China), Berlin, Copenhagen } \\
\text { Finger Plan (Denmark) }\end{array}$ & $\begin{array}{l}\text { Green belt system Cologne, Park } \\
\text { am Gleisdreieck (Berlin); mine } \\
\text { heaps in the Ruhr area; Emscher } \\
\text { river restoration (Ruhr) }\end{array}$ & $\begin{array}{l}\text { London Olympic Park, Chavesse } \\
\text { Park (Liverpool), Great Fen } \\
\text { Project (Huntingtonshire), } \\
\text { Winter Gardens (Sheffield), } \\
\text { Swansea Bay (Swansea), } \\
\text { Herrington Country Park } \\
\text { (Sunderland) }\end{array}$ \\
\hline
\end{tabular}

Notes: The principles and policies outlined in Table 1 are drawn from an extensive but not exhaustive review of the following sources: Ahern (2007), Austin (2014), Beatley (2000), Benedict and McMahon (2006), CABE Space (2004), Department of Communities and Local Government (2012), Hansen et al. (2015), Mell (2016), Rouse and Bunster-Ossa (2013).

Landscape planning in Germany is a form of sectoral planning which follows the general principles and procedures of formal spatial planning and policy-making (Riedel and Lange 2009). It is considered to be essentially decentralized with the corresponding legal and institutional frameworks, and responsibilities being clearly defined at each respective level. To ensure consistency and a common structure, key principles such as subsidiarity, feedback and sustainability apply to all levels of planning (Blotevogel et al. 2014; Mertins and Paal 2009; Pahl-Weber and Henckel 2008). A high level of rationality and coherence (i.e. Stage 1) can be noted here. Landscape planning aims to achieve strategic sustainable development by identifying limitations, the potential for better integration of various sub-systems, and by promoting more resilient ecological networks (von Haaren 2003). Furthermore, landscape planning is required to ensure the application of methodological quality and consistency to the context of an integrated and consistent network/system of green spaces.

In addition to the sectoral perspective of formal landscape planning, green infrastructure issues are promoted at different scales and within different approaches and instruments. At the federal 
level, green infrastructure planning is limited to the development of overarching guidelines and common principles (Stage 1 of the framework) providing a basis for specified state, regional and local planning. In 2006, the Ministerial Conference on Spatial Planning (MKRO), consisting of ministers with responsibility for spatial planning from the federation and the 16 Laender, presented the 'Concepts and Strategies for Spatial Development in Germany'. They have recently been updated, emphasizing sustainable development and the promotion of large-scale open green spaces. Moreover, national legislation addresses a number of common issues including sustainable development, ecological planning, green corridors and networks, biodiversity and quality of life, conforming to Stage 1 of the evaluative framework. For example, the Federal Nature Conservation Act (i.e. Bundesnaturschutzgesetz BNatSchG) expands the regulation of potential impacts on the natural environment and related compensation measures. Furthermore, the 'Strategy for Sustainable Development' (Bundesregierung 2002) and the 'National Strategy on Biological Diversity' (BMU 2007) provide additional guidance at the federal level.

Recent trends at the national-level support such a discursive framing of green infrastructure in Germany. In 2015, 'Green in the City - Liveable Future' was published, defining urban green space, outlining its functions and giving examples for best practice (BMUB 2015). It concludes that combining the multidimensional functions of urban greening with a strategic network approach is essential for green infrastructure planning and introduced the concept to a wider audience. In parallel the German federal government announced that the federal concept of 'green infrastructure' will be launched in the second half of the legislative period (2015-2017) ${ }^{2}$ (Deutscher Bundertag 2015). This aims to align existing sectoral visions for landscape management into a holistic investment framework to better plan for flood provision, the development of wetlands and biotope networks. In accordance with Stage 1, the continuity of this discursive process can be regarded as one of the key strengths of the German system. Due to the principle of subsidiarity there is, however, little evidence of a coordinated or formal process of delivery of green infrastructure at the national level in Germany (Stage 2). Here, certain 'discursive chains' (Servillo 2010) on green infrastructure planning and management can be observed, although the 'translation' of green infrastructure rhetoric remains bound to established instruments on the state level. State level planning ensures that national objectives are taken into account in regional and local planning promoting consistency of both procedures and content throughout, thus making use of the feedback loops presented in Stage 1. One example comes from the federal state of North Rhine-Westphalia which is redrawing its formal state development plan. The current draft outlines a set of delivery principles, and aims to protect and further develop green corridors by means of regional plans (Staatskanzlei NRW 2016). Thus, regional planning promotes a more detailed development of planning objectives within a designated territory identifying where and how investment should be delivered, and potentially allows regional planners to progress to Stage 2 of the investment process (Pahl-Weber and Henckel 2008).

However, in practice, formal regional planning lacks strength in terms of implementation and the practical coordination of its objectives. The regional level is therefore also the scale at which an increasing number of informal approaches and integrative partnerships are established to provide more efficient and practical solutions for green infrastructure planning (Stages $1+2$ ), hence they have become a laboratory for 'experimental regionalism' (Fürst 2010; Gualini 2004). Informal initiatives are beginning to address this void. For example, in the metropolitan region of Cologne/Bonn the draft and implementation of an informal 'Master Plan Green' aims to sensitize municipalities to regional-scale green infrastructure development (Reimer 2013). More initiatives of experimental regionalism can be observed in North Rhine-Westphalia, that is, the Masterplan Emscher Landscape Park in the Ruhr area (Projekt Ruhr GmbH 2005), the combination of landscape parks in Stuttgart (Kiwitt and Weidenbacher 2015) and regional parks elswhere in Germany (Gailing 2005). The regional planning association of the Regionalverband Ruhr (RVR) also recently published an evaluation reflecting on the evolution of the Emscher Landscape Park for the Ruhr metropolis highlighting an engagement with Stage 3 of the evaluative framework (RVR 2014). 
At the local level, formal, area-wide landscape plans are implemented in conjunction with comprehensive land use plans developed by local planning authorities (LPAs). Accordingly, there is scope within formal landscape plans to provide implementation strategies, which would include investment concepts as outlined in Stage 2 of the framework. In practice, however, they often appear to be disjointed from relevant stakeholder activities. Municipalities therefore often produce policies for the development of green spaces that act as guidance, and not statutory policy, for the development of green infrastructure (Stages $1+2$ ).

In summary, current examples from planning practice across Germany illustrate the popularity and importance of informal and experimental approaches for green infrastructure planning and management. As a consequence, green infrastructure planning is heavily located within Stages 1 and 2, where experimental implementation at a regional scale and local implementation vary depending on existing regulatory instruments of the framework. It therefore remains in the evolutionary stages of its development narrative. The emergence of initial forms of green infrastructure development at a number of scales in Germany does however follow the commonly observed pattern of a (partial) integration into well-established national and federal/local frameworks, as well as building on informal or alternative approaches in parallel. This represents a transition from Stage 1 to Stage 2 of the evaluative framework, where issues of practicality and conceptual performance in practice become more prevalent. Engagement with Stage 3 is though still relatively weak.

\section{Green infrastructure planning in England}

Backing for green infrastructure planning in England, as in Germany, has received varying levels of support from central government, LPAs, the development sector, and from environmental advocates. In its formative stages from 2003 to 2008/9 (see Mell 2015 for a detail discussion of its development), equivalent to Stage 1, a level of continuity is evident in how it was prescribed, which was largely driven by the evidence-based reporting of England's Community Forest Partnerships (Blackman and Thackray 2007). However, as the concept evolved and became established a more disparate approach to its implementation developed. These initial explorations, as discussed by Mell (2010), focussed most frequently on establishing a rationale for the categorization of green infrastructure based on existing land use classification (cf. Davies et al. 2006). Subsequent discussions, however, extended this debate as a grounded set of principles became established. Although a level of continuity can be identified within these initial conceptualizations more recent policy at a local, regional and national level in England indicates an continuing fluidity in the meaning, function and use of green infrastructure (Kambites and Owen 2006).

Furthermore, engagement from the UK government, and their subsidiary agencies (i.e. Natural England, the Forestry Commission and the Environment Agency), has increased since 2005 following the initial explorations of green infrastructure. This had two significant impacts: first, it raised the concept's visibility to a wider range of stakeholders, thus enabling a partial transition from Stage 1 to Stage 2, and second it simultaneously diluted (in one sense), whilst also extending the framing of green infrastructure by broadening its focus to cover a wider range of landscape and urban planning issues (Stage 2). This had the added benefit of enabling a more detailed 'vertical' discussion of green infrastructure to permeate through the tiers of government policy-making extending its coverage in praxis, as shown in Figure 2. However, such dissemination was constrained in some English regions by a weaker institutional understanding, and subsequent engagement with the principles of green infrastructure. In some cases this led to a disjointed dialogue between Stages 1 and 2 of the framework, for example, in the inclusion of green infrastructure in the draft Yorkshire \& Humber and London Regional Spatial Strategies (RSSs) was limited compared its integration in the final documents (Mell 2010). To fully appreciate the influence of such nuances it is important to reflect on the structural changes to planning policy in England following the initial conceptualization of green infrastructure. 

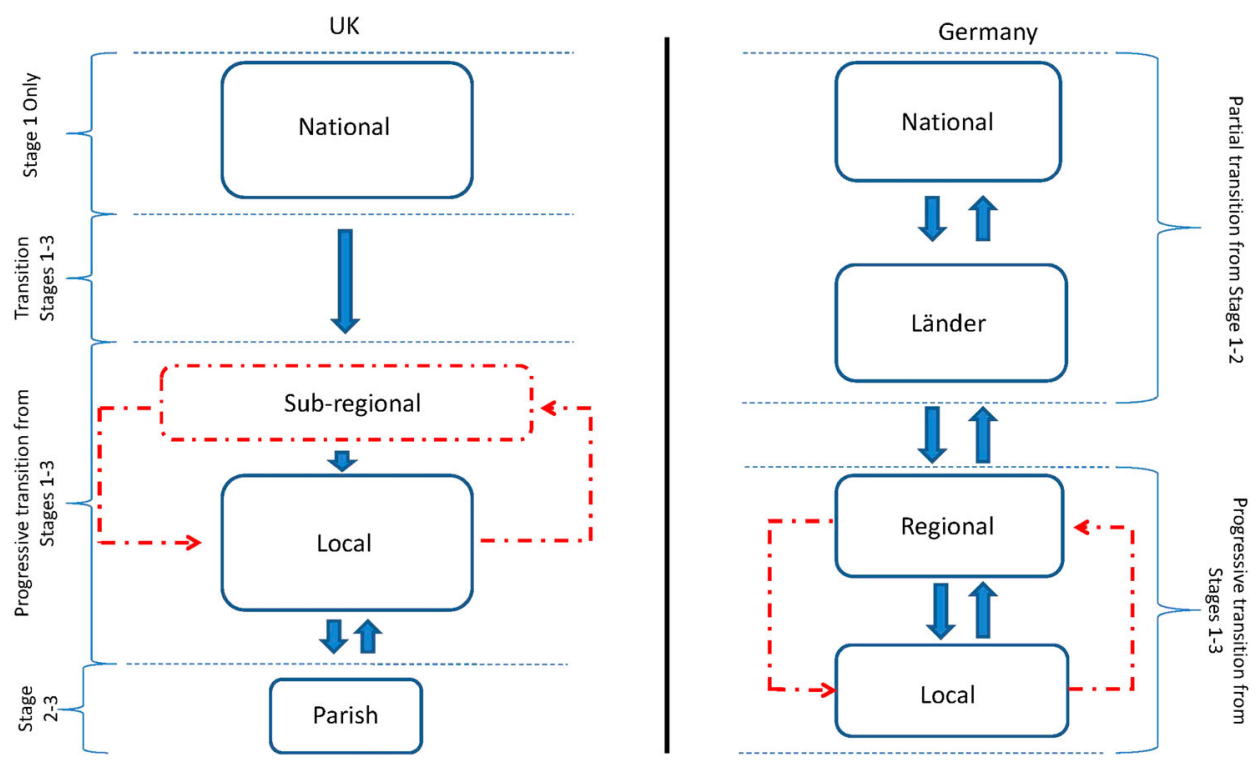

Figure 2. Green infrastructure policy frameworks in Germany and the UK.

The changing structure of planning policy and practice in the UK has been instrumental in the development of green infrastructure. Planning in the UK is a mixture of discretionary guidance and statutory policy (Tewdwr-Jones 2012), and is heavily centralized with the UK government setting policy mandates through the National Planning Policy Framework (NPPF) (Department of Communties and Local Government 2012). LPAs subsequently deliver these policies. The relationship between central government policy-making and LPA implementation has been considered by some to be conducive to effective planning control. Others, however, have suggested that the centrallocal governance dynamic has left a policy-gap where regional and sub-regional planning used to function (Marshall 2009).

The structural changes influencing this current central-local framework were instigated in 2011. The former New Labour government (1997-2010) were instrumental in promoting environmental and landscape planning establishing Planning Policy Statements (PPSs) and Planning Policy Guidance (PPGs), as a mechanism to support sustainable development. The publication of the Urban Renaissance (Department of Environment Transport and the Regions 1999) and Sustainable Communities agendas (Office of the Deputy Prime Minister 2003) were both examples which enabled green infrastructure practitioners to develop their agendas to align the concept with government mandates (Mell 2009). Each of these policy developments provided a framework for advocates to support green infrastructure discussions through an evidence-led process to policy-making: Stage 1 transitioning in to Stage 2 of the evaluative framework. Green infrastructure was though only latterly embedded within these policies suggesting that advocates and LPAs at a sub-national scale were initially unable or unwilling to feed into or feedback their strategic objectives with the new concept. However, as new environmental policy hooks became established green infrastructure became a more prominent policy discourse (i.e. Stage 1).

Moreover, prior to the establishment of the Conservative-Liberal Democrat coalition government (2010-2015), New Labour implemented a process of policy devolution through the establishment of Regional Development Agencies (RDA) and the development of the RSS structure (Tewdwr-Jones 2012). Working at the regional scale the RDAs, and other stakeholders, created strategic investment programmes, including green infrastructure, facilitating a knowledge-based transition through Stages 1 and 2 of the evaluative framework. Although, somewhat derided during their lifespan 
RSSs were among the small number of documents attempting to adopt a spatially robust framework for green infrastructure investment (Thomas and Littlewood 2010).

Unfortunately, this progressive mandate was not carried forward with the change in government post-2010. ${ }^{3}$ The coalition government rescinded the regional tier of planning creating a binary form of government: centralized policy-making and localized implementation (Cullingworth et al. 2015). The impact on green infrastructure policy was significant because it withdrew a supporting tier of strategic documentation and cycled stakeholders back to Stage 1 of the process. The post-revocation changes led green infrastructure advocates to reconsider their approaches to strategic policy-making and the implementation of green infrastructure. This could, however, be viewed positively as it enabled stakeholders to reconsider the pluralist nature of green infrastructure and align its regional/sub-regional value more effectively with other delivery mandates (Mell 2014).

It has also been suggested that the pluralistic nature of landscape planning has been one of the main barriers to the uptake of green infrastructure in England (Kambites and Owen 2006). Although the transition from Stage 1 through Stage 2 into Stage 3 in Figure 1 may appear predetermined it requires a level of reflectivity in both the formation and delivery of policy to ensure appropriate investment occurs. As Wright (2011) discussed the variance of praxis over the last decade (20052015) in England has limited, to some extent, political support for green infrastructure. Whereas, investment in other forms of infrastructure, that is, transport and housing, is normative within policy because it is perceived to deliver essential infrastructure requirements (Peel and Lloyd 2005). The rationale for green infrastructure has, however, been more fluid. As a result policy support has become increasingly heterogeneous at a sub-national scale in England, which reflects the interpretation of green infrastructure within the RSS process. Although variations in approach was visible between regions, there remained a retention of a meta-scale consensus amongst advocates focussing on the concept's principle and utility in landscape and urban planning (Kambites and Owen 2006; Thomas and Littlewood 2010).

Post-2010 there has not been an upscaling of these debates into national policy (Mell 2015). Although the NPPF makes reference to green infrastructure it does not provide sufficient depth when compared to sub-national policy (Department of Communties and Local Government 2012). ${ }^{4}$ Furthermore, where green infrastructure is discussed there is a lack of breadth underlining the differences in current documentation and the former PPS/PPGs. Despite the creation of an integrated environmental policy arena with the NPPF at the centre, there appears to be a lack of continuity between policy developed centrally and its application at a local scale (Shaw and Robinson 2012). In some locations this led to greater disjuncture between the planning and delivery of green infrastructure suggesting that the transition from Stages 1 to 2 can be undermined. Moreover, although there is rhetoric promoting green infrastructure within the NPPF (and more recent guidance), many commentators consider this to be an inadequate form of policy support (Hansen and Pauleit 2014; Mell 2013).

\section{Discussion and conclusion: consensus building and trans-location green infrastructure planning}

The fluidity of green infrastructure in England and Germany could be considered to align with the broader historical development narratives for the concept. Within this discussion Mell (2015) and other commentators (e.g. Benedict and McMahon 2006; Hansen and Pauleit 2014; Kambites and Owen 2006), discussed how the pluralistic nature of green infrastructure could be considered as both a hindrance and a benefit to its use. However, some commentators have argued that flexibility in approach should be seen as a positive, as it provides scope for planners, developers and advocates to shape investment in landscape and urban planning more effectively (Thomas and Littlewood 2010).

The discussions outlined above highlight the complexities associated with consensus building for green infrastructure planning in England and Germany. Due to variation in the structures of both 
planning systems, changes in government, as well as the creation/revocation of policy, the establishment of a transferable rationale for green infrastructure has proved difficult. Partly, this reflects the dynamism of planning discussions in Germany and England but also the relative novelty of green infrastructure praxis. Moreover, if the three development phases proposed by Mell (2015): exploration, expansion and consolidation are used as a bridge between these debate and the proposed evaluative framework we can argue that England has moved progressively, if slowly, through each stage, although development remains centred on a sub-national evolution. Green infrastructure development in Germany has not followed the same trajectory, as strategic debates focus predominately on the quality and usefulness of landscape resources at a national scale (Stage 1). Nevertheless, the implementation of the concept (Stage 2) at a regional and local-level have shown greater spatial divergence and therefore remains in its initial development stages. This is due, in part, to the fact that the German planning system has developed 'notable powers of persistence' (Blotevogel et al. 2014, 84), which limit the development of new green space development practise.

Moreover, the evolution of green infrastructure thinking and its integration into spatial planning praxis is time-consuming, especially when existing sectoral planning traditions are strong and/or inflexible (Lafortezza et al. 2013). In England these temporal constraints were circumvented through strong advocacy for the concept and its development in the now revoked RSS. Again, the maturity of the German planning system is a key difference to how green infrastructure is planned in England where the planning system has faced significant structural policy changes during the past decade. Reflecting on these issues can explain, to some extent, why the evaluative framework proposed in this paper may be an appropriate mechanism to identify transferable practices or commonalities between locations, and to move discussions on from data collection and synthesis to delivery and evaluation within policy.

Firstly, the plurality in decision-making witnessed in Germany and England highlights that developing consensus can be a protracted process. This reflects the evolutionary nature of green infrastructure, which has developed a consensual narrative regarding its principles but is applied within locally specific legal and spatial frameworks (Mell 2016). Establishing a rationale for green infrastructure, that is, Stage 1, may therefore entail a protracted timeframe, as advocates attempt to distil research findings into a supportive and coherent narrative. This is exacerbated where institutional support for environmental planning, through the auspices of central government (i.e. Defra) or sub-national bodies (i.e. Natural England or the Environment Agency), as seen in England, is perceived to be weak, suggesting that dialogue between stakeholders can be restricted (Kambites and Owen 2006). The fluidity of such approaches makes it increasingly difficult to (a) establish consensus and (b) facilitate transition from Stage 1 to Stage 2 of the evaluative process. Advocates of green infrastructure planning have, as a consequence, called for a reframing of this debate viewing consensus building as an essential component to integrate it within strategic plans, especially when compared to the current centralized process of policy formation (Van Den Brink, Van Der Valk, and Van Dijk 2006).

Secondly, the scale at which discussions occur has a direct influence on the framing of praxis. In both England and Germany questions have been raised which attempt to establish consensus on the most appropriate policy-level to locate green infrastructure planning (Albert and Von Haaren 2015; Mell 2015; Wilker, Rusche, and Rymsa-Fitschen 2016). Currently there is no universally accepted position on to this issue, although a number of authors have suggested that regional and sub-regional advocates are best placed to facilitate progress from Stage 1 and Stage 2 into Stage 3 (Lennon 2015; Mell 2014; Wilker and Rusche 2014). However, to facilitate this transition there is a corresponding need to allocate funding, time and identify expertise to enable stakeholders to produce evidence which can be integrated into planning policy. In England this occurred during the RSS process but has been undermined following their revocation. In Germany the formation of experimental regional partnerships, such as those in the Ruhr, Stuttgart and the Rhein, have been more successful in promoting the functionality of green infrastructure in sub-regional policy discussions (Kiwitt and Weidenbacher 2015; Projekt Ruhr GmbH 2005; Reimer 2013). 
The discussion presented in this paper illustrates that although we consider green infrastructure to be conceptually grounded in an international discourse, its use in national and sub-national planning practice remains varied. This raises questions about the transferability of green infrastructure policy/practice but does enable us to ask whether a singular consensual approach is the most appropriate outcome for those tasked with delivering landscape development. Within the academic and practitioner literature a number of commentators, including the authors of this paper, have argued that an alignment of the conceptual understandings of green infrastructure with practice in different locations could lead to a more coherent application of the concept's principles (cf. Mell 2015, 2016). This proposal has met with some success, although within territorial discussions of green infrastructure it has remained difficult to establish an evaluative framework which is sufficiently proactive in strategically aligning development priorities, yet reactive enough to the nuances of national planning structures and the subtleties of local context. The evaluative approach proposed within this paper, thus, presents a framework to bridge the difficulties of comparability between locations. The framework's three-stage process is also purposefully aspatial, providing scope for practitioners, advocates and decision-makers to employ localized knowledge and current exemplars projects/investments within an overarching understanding of green infrastructure to populate Stages 1 and 2 and, subsequently, feed into national-level policy. Thus, by understanding how we create a supportive policy environment based on dialogue and feedback channels between decision-makers and advocates (Stage 1), we can propose a more effective translation of the principles of green infrastructure into policy. This has the added benefit of addressing policy divergence and aiding continuity across spatial boundaries to promote a more reflective and grounded form of policy-making (Peel and Lloyd 2005). To achieve this therefore requires planners to consider how they establish a rationality for investment in green infrastructure (Stage 1), monitor its performance in practice (Stage 2), and evaluate its long-term functionality and conformance with policy mandates (Stage 3).

\section{Notes}

1. The German planning system is organized as a decentralized, multi-level system rendered complex by the federal structure of the country, whereby each of the 16 Länder has its own constitution, elected parliament and government. Although it is often cited as a model for comprehensive planning, spatial planning activities compete with a strong system of sectoral policies (Blotevogel et al. 2014; Fürst 2010). In England green infrastructure is not identified as a priority policy in the National Planning Policy Framework (Department of Communties and Local Government 2012). Alternatively, it is one of a series of approaches used in landscape planning to address development issues being developed most frequently by regional/sub-regional advocates and Local Planning Authorities (Mell 2015).

2. At the time of writing this had not yet been released.

3. With the election of the Conservative majority government in 2015 it is unlikely that this position will change.

4. In 2016 The UK government released additional guidance on how green infrastructure should be discussed in planning, which placed greater emphasis on its principles and benefits compared to the NPPF.

\section{Disclosure statement}

No potential conflict of interest was reported by the authors.

\section{References}

Ahern, J. 2007. "Planning and Design for Sustainable and Resilient Cities: Theories, Strategies and Best Practice for Green Infrastructure." In Water-centric Sustainable Communities, edited by V. Novotny, J. Ahern, and P. Brown, 135-176. Hoboken: Wiley-Blackwell.

Albert, C., and C. Von Haaren. 2015. "Implications of Applying the Green Infrastructure Concept in Landscape Planning for Ecosystem Services in Peri-Urban Areas: An Expert Survey and Case Study."Planning Practice \& Research 1-16.

Alexander, E. R., and A. Faludi. 1989. “Planning and Plan Implementation: Notes on Evaluation Criteria."Environment and Planning B: Planning and Design 16: 127-140. 
Allen III, W. 2012. Advancing Green Infrastructure at All Scales: From Landscape to Site. Environmental Practice 14 (1): 17-25.

Allin, S. 2011. “A New Understanding of Formal Land Use Plans in Germany.”International Journal of Sustainable Society 3 (4): 385-396.

Amati, M., and L. Taylor. 2010. “From Green Belts to Green Infrastructure.”Planning Practice and Research 25 (2): 143-155.

Andersson, E., S. Barthel, S. Borgström, J. Colding, T. Elmqvist, C. Folke, and A. Gren. 2014. "Reconnecting Cities to the Biosphere: Stewardship of Green Infrastructure and Urban Ecosystem Services.” Ambio 43 (4): 445-453.

Austin, G. 2014. Green Infrastructure for Landscape Planning: Integrating Human and Natural Systems. New York: Routledge.

BBSR (2014). 10 Jahre Stadtumbau West. Programmprofil und Praxis. Berlin: BMUB

Beatley, T. 2000. Green Urbanism: Learning from European Cities. Washington, DC: Island Press.

Benedict, M. A., \& McMahon, E. (2001). Green Infrastructure: Smart Conservation for the 21st Century Sprawl Watch Clearinghouse Monograph Series. Washington, DC: Sprawl Watch Clearinghouse.

Benedict, M. A., and E. T. McMahon. 2006. Green Infrastructure: Linking Landscapes and Communities. Urban Land (Vol. June). Washington, DC: Island Press.

Blackman, D., \& Thackray, R. (2007). The Green Infrastructure of Sustainable Communities. North Allerton: England's Community Forest Partnership.

Blotevogel, H. H., R. Danielzyk, and A. Münter. 2014. "Spatial Planning in Germany. Institutional Inertia and New Challenges." In Spatial Planning Systems and Practices in Europe. A Comparative Perspective on Continuity and Change, edited by M. Reimer, P. Getimis, and H. H. Blotevogel, 83-108. London: Routledge.

BMU (Bundesministerium für Umwelt, Naturschutz und Reaktorsicherheit) (2007). Nationale Strategie zur biologischen Vielfalt. Berlin: BMUB

BMUB (Bundeministerium für Umwelt, Naturschutz, Bau und Reaktorsicherheit) (2015). Grün in der Stadt für eine lebenswerte Zukunft. Berlin: BMUB

Bundesregierung (2002). Perspektiven für Deutschland. Unsere Strategie für eine nachhaltige Entwicklung. Berlin: Bundesregierung

CABE Space. 2004. Green Space Strategies: A Good Practice Guide. London: CABE Space.

Carneiro, G. 2013. "Evaluation of Marine Spatial Planning." Marine Policy 37 (37): 214-229.

Cullingworth, B., V. Nadin, T. Hart, S. Davoudi, J. Pendlebury, G. Vigar, ... T. Townshend. 2015. Town and Country Planning in the UK. 15th ed. Abingdon: Routledge.

Davies, C., Macfarlane, R., McGloin, C., \& Roe, M. (2006). Green Infrastructure Planning Guide. Anfield Plain: North East Community Forest

Department of Communties and Local Government (2012). National Planning Policy Framework. London: DCLG

Department of Environment Transport and the Regions (1999). Towards an Urban Renaissance. London: DETR

Deutscher Bundertag website. 2015. http://www.bundestag.de/presse/hib/2015_01/-/354424, Accessed July 8, 2015.

European Commission (2013). Communication From the Commission to the European Parliament, the Council, the European Economic and Social Committee and the Committee of the Regions: Green Infrastructure (GI) Enhancing Europes Natural Capital. Brussels: European Commission

Fábos, J. G. 2004. “Greenway Planning in the United States: its Origins and Recent Case Studies.”Landscape and Urban Planning 68 (2-3): 321-342.

Fürst, D. 2010. Raumplanung. Herausforderungen des deutschen Institutionensystems. Detmold: Verlag Dorothea Rohn.

Gailing, L. 2005. "Regionalparks - Grundlagen und Instrumente der Freiraumpolitik in Verdichtungsräumen.” Dortmunder Beiträge Zur Raumplanung, 121.

Gualini, E. 2004. “Regionalization as "Experimental Regionalism': The Rescaling of Territorial Policy- Making in Germany.”International Journal of Urban and Regional Research 28 (2): 329-353.

Hale, J., and J. Sadler. 2012. "Resilient Ecological Solutions for Urban Regeneration."Proceedings of the Institution of Civil Engineers - Engineering Sustainability 165 (1): 59-68.

Hansen, R., Buizer, M., Rall, E., DeBellis, Y., \& Davies, C. (2015). GREEN SURGE: Report of Case Study City Portraits. Appendix GREEN SURGE study on urban green infrastructure planning and governance in 20 European case studies. Copenhagen: University of Copenhagen

Hansen, R., and S. Pauleit. 2014. "From Multifunctionality to Multiple Ecosystem Services? A Conceptual Framework for Multifunctionality in Green Infrastructure Planning for Urban Areas." Ambio 43 (4): 516-529.

Henckel, D., L. von Kuczkowski, and P. Lau. 2010. Planen - Bauen - Umwelt: Ein Handbuch. Wiesbaden: VS Verlag fuer Sozialwissenschaften.

James, P., K. Tzoulas, M. D. Adams, A. Barber, J. Box, J. Breuste, and C. Ward Thompson. 2009. "Towards an Integrated Understanding of Green Space in the European Built Environment."Urban Forestry \& Urban Greening 8 (2): 65-75. http://doi.org/10.1016/j.ufug.2009.02.001.

Jongman, R., and G. Pungetti. 2004. Ecological Networks and Greenways: Concept, Design and Implementation. Edited by R. Jongman and G. Pungetti. Cambridge: Cambridge University Press. 
Kambites, C., and S. Owen. 2006. "Renewed Prospects for Green Infrastructure Planning in the UK 1."Planning Practice and Research 21 (4): 483-496.

Kiwitt, T., and S. Weidenbacher. 2015. "Grüne Infrastruktur für die Region. Der Landschaftspark Region Stuttgart. RaumPlanung."Fachzeitschrift für Räumliche Planung und Forschung 180 (4): 65-71.

Lafortezza, R., C. Davies, G. Sanesi, and C. Konijnendijk. 2013. Green Infrastructure as a Tool to Support Spatial Planning in European Urban Regions. iForest - Biogeosciences and Forestry 6: 102-108.

Lennon, M. 2014. "Presentation and Persuasion: The Meaning of Evidence in Irish Green Infrastructure Policy." Evidence \& Policy: A Journal of Research, Debate and Practice 10 (2): 167-186.

Lennon, M. 2015. “Green Infrastructure and Planning Policy: A Critical Assessment.” Local Environment 20 (8): $957-$ 980.

Liebenath, M., A. Blum, and S. Sturzriemer. 2010. “Transboundary Cooperation in Establishing Ecological Networks: The Case of Germany's External Borders." Landscape and Urban Planning 94 (2): 84-93.

Llausàs, A., and M. Roe. 2012. "Green Infrastructure Planning: Cross-National Analysis Between the North East of England (UK) and Catalonia (Spain).” European Planning Studies 20 (4): 641-663.

Marcucci, D. J., and L. M. Jordan. 2013. "Benefits and Challenges of Linking Green Infrastructure and Highway Planning in the United States."Environmental Management 51 (1): 182-197.

Marshall, T. 2009. "Planning and New Labour in the UK." Planning Practice and Research 24 (1): 1-9.

Mazza, L., Bennett, G., De Nocker, L., Gantioler, S., \& Losarcos, L. (2011). Green Infrastructure Implementation and Efficiency. Final Report for the European Commission DG Environment on Contract ENVB2SER20100059. London: Institute for European Environmental Policy

McHarg, I. L. (1969). Design with Nature (Wiley Series in Sustainable Design). New York: John Wiley \& Sons

Mell, I. C. 2009. "Can Green Infrastructure Promote Urban Sustainability?" Proceedings of the Institution of Civil Engineers - Engineering Sustainability 162 (1): 23-34.

Mell, I. C. (2010). Green Infrastructure: Concepts, Perceptions and its Use in Spatial Planning. Ph.D. diss.,. Newcastle: University of Newcastle

Mell, I. C. 2013. “Can you Tell a Green Field From a Cold Steel Rail ? Examining the 'Green' of Green Infrastructure Development." Local Environment: The International Journal of Justice and Sustainability: The International Journal of Justice and Sustainability 18 (2): 37-41.

Mell, I. C. 2014. "Aligning Fragmented Planning Structures Through a Green Infrastructure Approach to Urban Development in the UK and USA." Urban Forestry \& Urban Greening 13 (4): 612-620.

Mell, I. C. 2016. Global Green Frastructure: Lessons for Successful Policy-Making, Investment and Management. Abingdon: Routledge.

Mell, I. C. 2015. “Green Infrastructure Planning: Policy and Objectives.” In Handbook on Green Infrastructure: Planning, Design and Implementation, edited by D. Sinnett, S. Burgess, and N. Smith, 105-123. Cheltenham: Edward Elgar Publishing Ltd.

Mertins, G., and M. Paal. 2009. "Regional Planning Within the German Institutional Planning Framework Instruments and Effectiveness." Investigación \& Desarrollo 17 (2): 242-267.

Natural England \& Landuse Consultants (2009). Green Infrastructure Guidance. Peterborough: Natural England

Office of the Deputy Prime Minister (2003). Sustainable Communities: Building for the Future. London: ODPM

Pahl-Weber, E., and D. Henckel. 2008. The Planning System and Planning Terms in Germany - a Glossary. Studies in Spatial Development. Hannover: Academy of Spatial Research (ARL).

Peel, D., and G. Lloyd. 2005. "Development Plans, Lesson-Drawing and Model Policies in Scotland." International Planning Studies 10 (3-4): 265-287.

Projekt Ruhr GmbH (Ed.). 2005. Masterplan Emscher Landschaftspark 2010. Essen: Klartext Verlag. 2005.

Reimer, M. 2013. Planning Cultures in Transition. Sustainability Management and Institutional Change in Spatial Planning. Sustainability 5 (11): 4653-4673.

Riedel, W., and H. Lange. 2009. Landschaftsplanung. Wiesbaden: Spektrum Akademischer Verlag.

Roe, M., and I. C. Mell. 2013. "Negotiating Value and Priorities : Evaluating the Demands of Green Infrastructure Development." Journal of Environmental Planning and Management 56 (5): 37-41.

Rouse, D. C., and I. Bunster-Ossa. 2013. Green Infrastructure: A Landscape Approach [Paperback]. Chicago: APA Planners Press.

RVR (2014). Trägerschaft für den Emscher Landschaftspark. Evaluierungsbericht 2014. Essen: Druckhaus Cramer

Rydin, Y. 2013. The Future of Planning: Beyond Growth Dependence. Bristol: Polity Press.

Servillo, L. 2010. "Territorial Cohesion Discourses: Hegemonic Strategic Concepts in European Spatial Planning." Planning Theory and Practice 11 (3): 397-416.

Shaw, K., and F. Robinson. 2012. “From 'Regionalism' to 'Localism': Opportunities and Challenges for North East England.” Local Economy 27 (3): 232-250.

Siemens AG (2011). Asian Green City Index: Assessing the Environmental Performance of Asias Major Cities. Munich: Siemens AG

South Yorkshire Forest Partnership \& Sheffield City Council (2012). The VALUE Project: The Final Report. Sheffield: South Yorkshire Forest Partnership \& Sheffield City Council 
Staatskanzlei des Landes Nordrhein-Westfalen (NRW) (2016). Landesentwicklungsprogramm Nordrhein-Westfalen (LEP NRW).Entwurf zur Zuleitung an den Landtag von Nordrhein-Westfalen Nach Kabinettsbeschluss am 5.7.2016. Düsseldorf: Staatskanzlei des Landes Nordrhein-Westfalen (NRW)

Tewdwr-Jones, M. 2012. Spatial Planning and Governance: Understanding UK Planning. Basingstoke: Palgrave Macmillan.

Thomas, K., and S. Littlewood. 2010. "From Green Belts to Green Infrastructure? The Evolution of a New Concept in the Emerging Soft Governance of Spatial Strategies.” Planning Practice and Research 25 (2): 203-222.

Town \& Country Planning Association (2012). Creating Garden Cities and Suburbs Today: Policies, Practices, Partnerships and Model Approaches A Report of the Garden Cities and Suburbs Expert Group. London: TCPA

Van Den Brink, A., A. Van Der Valk, and T. Van Dijk. 2006. "Planning and the Challenges of the Metropolitan Landscape: Innovation in the Netherlands."International Planning Studies 11 (3-4): 147-165.

Vandermeulen, V., A. Verspecht, B. Vermeire, G. Van Huylenbroeck, and X. Gellynck. 2011. “The Use of Economic Valuation to Create Public Support for Green Infrastructure Investments in Urban Areas."Landscape and Urban Planning 103 (2): 198-206.

von Haaren, C (2003). Für eine Stärkung und Neuorientierung des Naturschutzes Bericht über das Sondergutachten des Rates von Sachverständigen für Umweltfragen. Biologische Vielfalt Leben in und mit der Natur. Jahrbuch für Naturschutz und Landschaftspflege. 54, 69-87. Bonn: BBNundesverband Beruflicher Naturschutz (Hrsg.)

Ward Thompson, C., P. Aspinall, and S. Bell. 2010. Innovative Approaches to Researching Landscape and Health, edited by C. Ward-Thompson, P. Aspinall, and S. Bell. Abingdon: Routledge.

Weber, T., A. Sloan, and J. Wolf. 2006. "Maryland's Green Infrastructure Assessment: Development of a Comprehensive Approach to Land Conservation."Landscape and Urban Planning 77 (1-2): 94-110.

Werquin, A. C., B. Duhem, G. Lindholm, B. Oppermann, S. Pauleit, and S. Tjallingii. 2005. Green Structure and Urban Plannng - Final Report, edited by A. C. Werquin, B. Duhem, G. Lindholm, B. Oppermann, S. Pauleit, and S. Tjallingii. Luxembourg: Office of Official Publications of the European Commission.

Wilker, J., and K. Rusche. 2014. Economic Valuation as a Tool to Support Decision-Making in Strategic Green Infrastructure Planning. Local Environment 19 (6): 702-713. doi:10.1080/13549839.2013.855181.

Wilker, J., K. Rusche, and C. Rymsa-Fitschen. 2016. Improving Participation in Green Infrastructure Planning. Planning Practice \& Research 1-21. doi:10.1080/02697459.2016.1158065.

Wright, H. 2011. "Understanding Green Infrastructure : The Development of a Contested Concept in England.”Local Environment: The International Journal of Justice and Sustainability 16 (10): 37-41. 